\title{
The Brazilian Electricity Supply for 2030: A Projection Based on Economic, Environmental and Technical Criteria
}

\author{
Claudia Cristina Sanchez Moore ${ }^{1}$, Erik Eduardo Rego ${ }^{2}$ \& Luiz Kulay ${ }^{1}$ \\ ${ }^{1}$ Chemical Engineering Department - Polytechnic school, University of Sao Paulo, Brazil \\ ${ }^{2}$ Production Engineering Department - Polytechnic school, University of Sao Paulo, Brazil \\ Correspondence: Luiz Kulay, Chemical Engineering Department - Polytechnic school, University of Sao Paulo, \\ Brazil. E-mail: luiz.kulay@usp.br
}

Received: October 5, 2017

Accepted: October 24, 2017

Online Published: October 27, 2017

doi:10.5539/enrr.v7n4p17

URL: https://doi.org/10.5539/enrr.v7n4p17

\begin{abstract}
The expansion of the Brazilian energy supply from fossil sources prompted environmental concerns about the emission of Green House Gases (GHG). Furthermore, the Brazilian government was committed to the United Nations Framework Convention on Climate Change (UNFCCC) to reduce GHG emissions by $43 \%$ by 2030 , compared to 2005. The aim of this study was to design the Brazilian electricity mix for 2030, while taking into account economic, technical and environmental criteria. In order to get this, Linear Programming optimization has been applied to obtain an electricity matrix with minimum cost of the Brazilian electricity generation system, considering GHG emission constraints - defined via the Life Cycle Assessment (LCA) technique -, as well as capacity generation and supply needs. In addition, LCA was also applied to obtain the environmental performance of the projected scenario and results were compared with those of 2005 and 2015. The analysis depicted that renewable sources represent $88 \%$ of the projected Brazilian electricity production in 2030, mainly hydropower, which accounts for $66 \%$. In terms of Climate Change there is an impact reduction of $12 \%$ compared to 2005 , while other categories such as Ionized Radiation and Terrestrial Ecotoxicity doubled and upped more than forty times. These findings led to conclude that environmental management should not be limited to GHG analysis, and must encompass other adverse effects. Moreover, this reinforces the importance of conducting analyses such as those provided by the LCA approach and include these results in the planning and decision-making processes of the energy sector.
\end{abstract}

Keywords: electricity supply mix, energy planning, environmental management, Life Cycle Assessment, linear programming optimization

\section{Introduction}

Historically, the world energy consumption has changed due to population and urban growth in conjunction with industrialization processes. In Brazil, according to the Energy Research Company (EPE 2015), between 2006 and 2015 there was an increase of $34 \%$ in electricity demand. The industrial sector was the largest consumer, accounting for $38 \%$ of the national power requirement of 2015 , followed by the residential sector, with $25 \%$.

This situation partly derives from governmental measures such as tax reduction for the purchase of specific goods (i.e., household appliances) and social programs that favor the development and expansion of the Brazilian energy system (Chen et al., 2017; Guerra et al., 2015; Lima \& Carvalho, 2016; Sáez-Matinez et al., 2016).

Electricity supply in Brazil is mostly supported by hydroelectric generation systems due to the availability of water resources in the country. Most of these resources, however, have already been exploited and those still available are located in regions protected by social and environmental restrictions. This occurs with the North region, which embraces the Brazilian Amazon, and whose hydroelectric potential is about $100 \mathrm{GW}$ (Dantas et al., 2017; Pereira et al., 2012). One limitation of this model lies, however, in the climatic seasonality, increasingly more frequent in Brazil, and typified by a decline in rainfall levels that negatively impact the supply of water resources for hydroelectric generation. This phenomenon makes the national electricity matrix very sensitive to change and leads to serious consequences in the economic and social sphere (Jacobi et al., 2015; Moreira et al., 2015). Table 1 depicts the Brazilian Electricity Supply along two different moments: in 2005, a period during which the contribution of hydroelectricity exceeded $91 \%$ due to the high rainfall level; and in the last four years, when this 
participation achieved no more than 68\% (2016). In addition, the hydropower source decreased $9.4 \%$ between 2013 and 2014 as a result of a water crisis in several Brazilian municipalities.

Table 1. Composition of the Brazilian Electricity Matrix by source: 2005 and 2013-2016 (\%)

\begin{tabular}{lccccc}
\hline Source & 2005 & 2013 & 2014 & 2015 & 2016 \\
\hline Hydropower & 91.2 & 70.6 & 65.2 & 64.0 & 68.1 \\
Biomass & 0.00 & 7.60 & 7.31 & 8.00 & 8.20 \\
Wind & 0.16 & 1.10 & 2.01 & 3.44 & 5.41 \\
Natural Gas & 3.14 & 11.3 & 13.0 & 12.9 & 9.12 \\
Oil derivatives & 1.88 & 4.40 & 6.89 & 4.75 & 3.68 \\
Nuclear & 2.24 & 2.40 & 2.49 & 2.40 & 2.60 \\
Solar & $\mathrm{NR}^{1}$ & $\mathrm{NR}$ & $\mathrm{NR}$ & 0.01 & $\mathrm{NR}$ \\
Coal and coal products & 1.38 & 2.60 & 3.10 & 4.50 & 2.89 \\
Total (TWh) & 442 & 611 & 624 & 616 & 620 \\
\hline
\end{tabular}

Note. NR: non representative. The grade is applied for contributions of less than $0.01 \%$.

Source: Adapted from Energy Research Company - EPE (2014-2017).

In order to increase the capacity and enhance energy security in the country, alternatives were sought, mainly fossil resources such as coal, petroleum derivatives, and natural gas. These accounted for $22 \%$ of the national electricity mix in 2015 (EPE, 2015; Kileber \& Parente, 2015). The low price of coal in the international market and the development and exploitation of domestic pre-salt oil reserves favored fossil sources more than the others (Santos et al., 2017). Nevertheless, the expansion of the energy supply to such sources prompted concerns in the environmental sciences and several discussions about the energy sector's share in the emission of Green House Gases (GHG) have been initiated. Many authors point out that electricity generation accounts for approximately $40 \%$ of total $\mathrm{GHG}$ emissions (i.e., $\mathrm{CO}_{2}, \mathrm{CH}_{4}$ and $\mathrm{N}_{2} \mathrm{O}$ ) that lead to global warming and climate Change (Abbaspour et al., 2011; Alam et al., 2016; Chen et al., 2017; Elum \& Momodu, 2017; Gueller \& Meneses, 2016; Hardisty et al., 2012; Patel et al., 2016; ShafiepourMotlagh et al., 2016; Turconi et al., 2013; von Sperling, 2012). Additionally, we must also consider pressing concerns such as the depletion of natural resources, economic factors associated with changes in oil prices, as well as social factors (Guerra et al., 2015; Patel et al., 2016).

Global policy agreements such as the Kyoto Protocol, established by the United Nations (UN) in 1997, and the Paris Agreement on Climate Change, which aim to reduce GHG emissions in order to curb global warming, encourage renewable and sustainable energy systems. This approach seeks to decarbonize human activities in order to preserve natural resources that are vital for supporting global economic activities and securing social growth and development (Almer \& Winkler, 2017; Foley et al., 2017; Lau et al., 2012; Mossalanejad, 2012).

In this context, Brazil stands out by supporting, through the Alternative Energy Sources Incentive Program (PROINFA) and The Ten-year Energy Expansion Plan (PDE), investments in systems based on renewable sources (wind, solar, and biomass) to supplement hydropower generation units (Pao \& Fu, 2013; Santos et al., 2017). Projections of the Brazilian Energy Matrix depict scenarios based on established targets for mitigating the impacts associated with GHG emissions by the year 2030 compared with 2005 . The basic guideline is to prioritize the use of renewable sources, especially biomass and wind, and even urban waste, to offset for the possible long-term depletion of the national hydroelectric potential and the climatic seasonality (Guerra, 2015).

However, some of these renewable energy technologies are considered economically non-competitive compared with conventional fossil energy generation systems. Also, the exploration of oil from pre-salt and the discovery of gas wells that provide a large amount of fuels for energy purposes could turn the Brazilian matrix back to fossil fuels, which would result on a new conflict between energetic policies and environmental agreements (Rocha et al., 2015; Vahl \& Casarotto, 2015).

In this context, multicriteria studies dealing with issues such as economic growth, security in energy supply and mitigation of climate change can lead to a new consideration of sustainability (Chen et al., 2017; Grilli et al., 2016, 2017). Authors such as Santoyo-Castelazo and Azapagic (2014) and Santos et al. (2015) emphasize that development of energy systems requires consideration of environmental, technical, economic, and social sustainability dimensions in order to suitably support decision-making processes in the sector. Following in the same direction Blok et al. (2015) point that new and improved production management techniques are required to develop cleaner and sustainable energy systems. Factors such as costs, capacity and location must be considered 
when designing and planning sustainable energy systems. Moreira et al. (2015) draw attention to the fact that energy planning requires sustainability assessment as part of the decision process, always taking into account issues raised by the different stakeholders.

Costa et al. (2017) state that one of the major challenges for policy makers and investors, is to create an electricity mix in which a balance between energy security, affordable costs and environmental concerns is achieved. To overcome these situation in which economic, technical, social, and environmental variables conflict, multi-objective optimization techniques are sorely useful. Vidal-Amaro et al. (2015) presented a study in which an optimal mix of renewable energy sources (RES) and fossil fuels for the Mexican electricity matrix was calculated to achieve a $35 \%$ RES electricity share target for 2024, taking into account the hourly values of RES production and the electricity demand.

In recent years, an approach known as Life Cycle Assessment (LCA) has called attention due to its potential for assessing the environmental dimension of multi-criteria studies for energy systems, given its analytical systemic and quantitative capabilities. Using LCA Turconi et al. (2013) compared different sources for electricity generation, showing that for fossil fuel technologies, the majority of emissions come from plant operation. In the case of biomass and nuclear systems, fuel provision had the largest contribution for total life cycle emissions.

Stamford and Azapagic (2014) evaluated the life cycle sustainability of different electricity scenarios for the UK, extending to 2070. The author observed that best overall environmental performance was obtained for a very low-carbon mix with nuclear and renewable sources, despite the increase of impacts such as terrestrial eco-toxicity. Also from the LCA perspective, Dinato and Kulay (2015) assessed the environmental impact of the Brazilian grid for the period 2006-2013 to verify the effect of the use of different sources. Results shown an increase in the environmental impact due to the growing participation of fossil fuels in the Brazilian grid for that period. Gueller and Meneses (2016) studied environmental impacts associated to the construction, operation, and decommissioning of a hydroelectric power plant, based on LCA. In that case, the construction phase showed the highest contribution due to the use of steel and concrete.

In parallel, LCA methods have been also incorporated into optimization problems allowing the increase of robustness of models and results (Argaski et al., 2016; Hacatoglu et al., 2015; Maxim, 2014; Santos et al., 2017; Stamford \& Azapagic, 2014). However, except for Portugal-Pereira et al. (2016), which evaluated the implications of applying Life Cycle Assessment of GHG emissions (LCA-GHG) into the optimization of the Brazilian power generation mix through 2050, other studies with similar approaches were not found in the technical-academic literature.

In order to fill that gap this study aims to design the Brazilian electricity mix for 2030, while taking into account economic, technical and environmental criteria. Linear Programming (LP) optimization was used to obtain the minimum cost of the Brazilian electricity generation system considering environmental constraints, defined via LCA, as well as capacity generation and supply needs for 2030. Additionally, LCA was applied to obtain the environmental performance of the projected scenario and results were compared with those of 2005 and 2015 . We expected that the findings provided by this investigation could contribute to future actions of managing related to the Brazilian energy planning.

\section{Method}

The method established for projecting the Brazilian Electricity Matrix for 2030 followed three steps: (i) to design the Brazilian Electrical Matrix for the year 2030; (ii) estimate the environmental impacts for that scenario from an LCA perspective; and (iii) comparing the impact profile results with those of 2005 and 2015, also obtained via LCA. A detailed description of the above mentioned steps, as well as data and premises used in this study, are presented in the following sections.

\subsection{Brazilian Electricity Matrix Design}

As established in 2015 during the Conference of the Parties COP21 of the United Nations Framework Convention on Climate Change (UNFCCC), 195 countries committed to reduce GHG emissions in order to limit global warming and mitigate climate change. To achieve that goal, governments publicly set their own commitments post-2020 known as their intended Nationally Determined Contributions (iNDC) (MRE, 2015).

In the case of Brazil, the iNDC the federal government presented to the UNFCCC committed to reduce GHG emissions by $37 \%$ by 2025 , and $43 \%$ by 2030 , compared to 2005 , when $2.35 \mathrm{Gt}^{\circ} \mathrm{CO}_{2 \text { eq }}$ were emitted mainly due to events of land use change, agricultural activities, and energy production (SEEG, 2014). One of the defined measures to reach that levels is to increase the share of sustainable bioenergy in its energy matrix to approximately $18 \%$ by 2030 . 
According to official estimates carried out by the Ministry of Mines and Energy in 2006 electricity generation would have the highest GHG emission growth rate over the period ( 25 years), around $5.0 \%$ per year, increasing the share of the power sector from $9.0 \%$ in 2005, to just under $14 \%$ in 2030 (MME, 2007). This performance would provide a total gross GHG contribution in terms of impact of $185 \mathrm{Mt} \mathrm{CO}_{2}$ eq per year (MME, 2007).

Starting from these conditions, an electricity matrix for 2030 was defined as one in which the total cost of the generation system, taking into account the combination of different energy sources, was minimum, so that an annual impact provided by GHG emissions was lower than $185 \mathrm{Mt} \mathrm{CO}_{2 \text { eq }}$ and the electricity demand projected for that year $(1,030 \mathrm{TWh})$ would be met. This optimization problem can be addressed by Linear Programing (LP). It is possible to describe the situation under analysis from the system comprising the equation (1) and the inequations (2) to (5), which consist of the constraints to be met by the model.

$$
\operatorname{Min}\left(C_{T}\right)=\sum\left(X_{i} . C_{i}\right)
$$

Subject to:

$$
\begin{gathered}
\sum X_{i}-1.03 E+09=0 \\
\sum\left(X_{i} . I_{i}\right)-1.85 E+11 \leq 0 \\
X_{i}-G C_{i, \max x} \leq 0 \\
G C_{i, \text { min }}-X_{i} \leq 0
\end{gathered}
$$

$C_{T}$ : Total electricity generation cost (USD/yr)

$X_{i}$ : Electricity generation from source $(i)(\mathrm{MWh} / \mathrm{yr})$

$C_{i}$ : Electricity generation cost from source (i) (USD/MWh)

$I_{i}$ : Impact from electricity generation from source (i) $\left(\mathrm{kg} \mathrm{CO}_{2 \mathrm{eq}} / \mathrm{MWh}\right)$

$G C_{i . m a ́ x}:$ Maximum generation capacity from source (i) $(\mathrm{MWh} / \mathrm{yr})$

$G C_{\text {i.minn }}$ : Minimum generation capacity from source (i) $(\mathrm{MWh} / \mathrm{yr})$

Electricity generation costs by source $\left(C_{i}\right)$ have been obtained from data and information provided by the International Energy Agency (IEA) (IEA, 2015). The impact by source $\left(I_{i}\right)$, expressed as $\mathrm{kg} \mathrm{CO}_{2}$ eq $/ \mathrm{MWh}$ electricity, was obtained from Sims et al. (2007). Additional restrictions, related to generation capacity $\left(G C_{i}\right)$ and technical limits by source where considered as well. The values adopted for these parameters are presented in Table 2. The optimization software Optimization Modeling Software for Linear, Nonlinear, and Integer Programming - LINGO v. 17.0.0.52 (LINDO 2017) has been used for the LP model.

Table 2. Adopted values for $\mathrm{C}_{\mathrm{i}}$ and $\mathrm{I}_{\mathrm{i}}$, and capacity restrictions

\begin{tabular}{lcccc}
\hline \multirow{2}{*}{ Source } & $\mathrm{C}_{\mathrm{i}}$ & $\mathrm{I}_{\mathrm{i}}$ & \multicolumn{2}{c}{$\mathrm{GC}_{\mathrm{i}}(\mathrm{TWh})$} \\
\cline { 3 - 5 } Hydropower & 64.09 & 153 & $\mathrm{Min}$ & $\mathrm{Max}$ \\
Biomass & 166.2 & 25.0 & 46.5 & 678 \\
Wind & 112.3 & 11.2 & 11.7 & 64.3 \\
Natural Gas & 106.6 & 1,040 & 75.0 & 195 \\
Oil derivatives & 300.3 & 880 & 0.00 & 116 \\
Nuclear & 98.06 & 7.66 & 14.0 & 57.6 \\
Solar & 168.0 & 75.2 & 0.00 & 5.8 \\
Coal and coal products & 99.12 & 1,090 & 0.00 & $51 \mathrm{E}-02$ \\
\hline
\end{tabular}

(IEA, 2015; ANEEL, 2017).

\subsection{LCA Modelling}

LCA is defined as a technic for supporting decision-making processes, which performs an analysis of the environmental effects of a product (or service) over its entire life cycle, encompassing the stages of the production chain: extracting of raw materials and product manufacturing); the use of the product (or service provision): including activities of re-use, and maintenance; possible post-consumption practices of recycling and operations associated to final disposal; and actions of transportation and distribution (Zbicinski et al., 2006). 
As for the methodological framework LCA includes four operative phases: Goal and Scope definition; Life Cycle Inventory (LCI); Life Cycle Impact Assessment (LCIA), and Results Interpretation (ISO, 2006). This study followed the guidelines and requirements described in the ISO 14044 (ISO 2006) standard. LCA was adopted with an attributional focus and a "cradle-to-gate" approach; i.e. that were considered only stages of the supply chain of each power generating source that is part of the Brazilian matrix. Furthermore, the GHG emissions have been calculated for a production of 1.0 MWh of electricity. Figure 1 summarizes the elements that compose the model evaluated in the study.

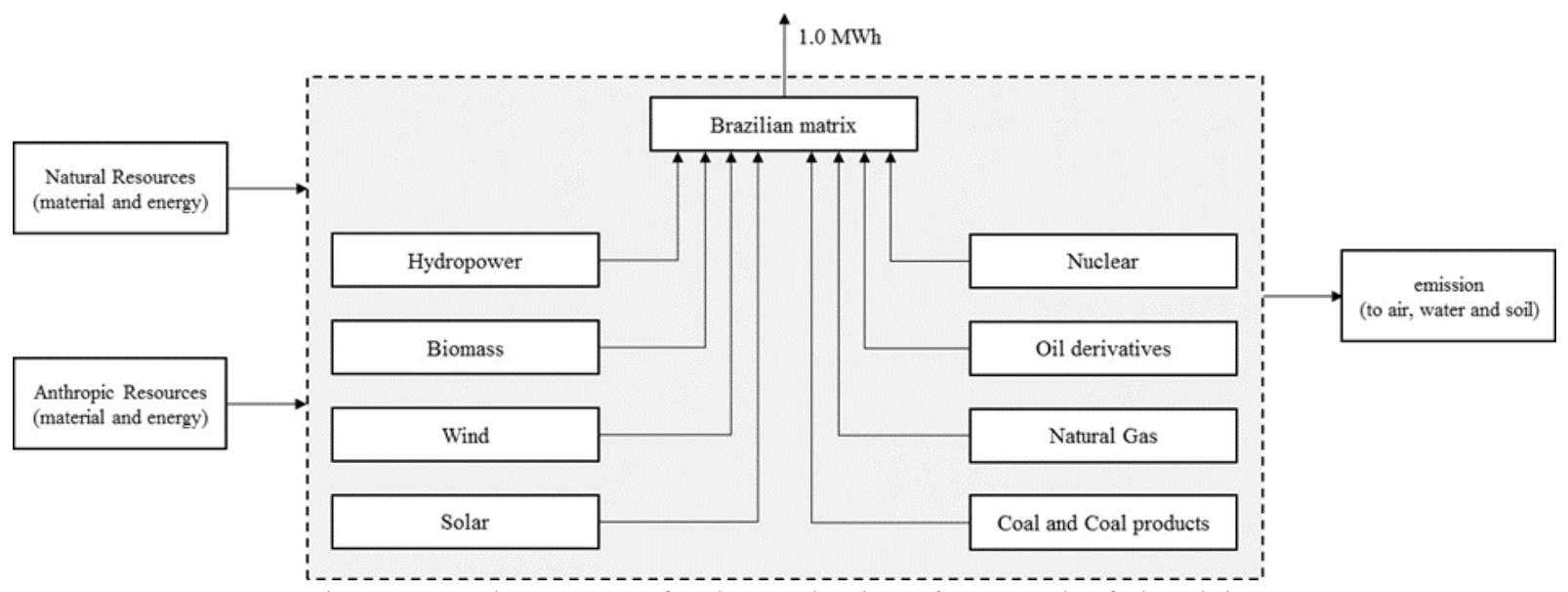

Figure 1. Product System for the production of 1.0 MWh of electricity

The modelling of the electric generation is based on secondary data collected from the Ecoinvent Database (Dones et al., 2007a) and adapted to the Brazilian condition along the periods evaluated in this investigation. For hydropower generation, data are associated to materials used during the construction of power plant such as cement, gravel, steel and explosives, as well as energy consumption, particle emissions, transport, land use, requirements of lubricating oil, and GHG emissions generated during the operation of the plant. In terms of natural gas (Faist Emmenegger et al. 2007) and oil derivatives systems (Jungbluth 2007), data include field exploration, production and purification, transport, oil refining, distribution, and combustion in power plants.

For biomass cogeneration systems, data include production of sugarcane, fermentation of sugar juice, including materials, energy uses, infrastructure, and emissions. This multi-functional process delivers the following co-products: "Ethanol, 95\% in $\mathrm{H}_{2} \mathrm{O}$, at plant" and "Electricity, bagasse at fermentation plant" (Jungbluth et al., 2007). For coal products, data include hard coal mining, processing, transportation, distribution and combustion in power plants (Röder et al., 2004).

The modelling of nuclear cycles includes power generation at pressurized water reactors, the technology used in the Brazilian nuclear plants. Other data referred to in the model include the following steps: mining, milling, conversion, enrichment via diffusion, fuel fabrication and interim storage, as well as infrastructure, spent fuel conditioning, and geological final repositories (Dones, 2007a). For wind systems, data include the construction of fixed and moving parts; in this case, datasets accounts for different construction materials, such as concrete and still for fixed parts, and plastics, glass fiber, aluminium, and copper for moving parts, their processing and transport. Land use for the basement and energy requirements are included as well (Burger \& Bauer, 2007). Finally, data for solar generation describes the production of electricity with photovoltaic power plants, and include quartz reduction, silicon purification, wafer, panel, and laminate production, manufacturing of converter and supporting structure. Transport of materials and end of life waste treatment processes are also considered (Jungbluth \& Tuchschmid, 2007).

\subsubsection{Life Cycle Inventory (LCI)}

The consolidated LCI of the Electrical Matrix of Brazil was elaborated from the following databases: (i) Hydropower: "Electricity, hydropower, at reservoir power plant/BR U”; (ii) Biomass: "Electricity, bagasse, sugarcane, at fermentation plant/BR U”; (iii) Wind: "Electricity, at wind power plant/ RER U; (iv) Natural Gas: "Electricity, natural gas, at power plant/BR U; (v) Oil derivatives: "Electricity, oil, at power plant/BR U; (vi) Solar: "Electricity, production mix photovoltaic, at plant/CH U”; (vii) Nuclear: "Electricity, nuclear, at power 
plant//CH U”; (viii) Coal and coal products: "Electricity, hard coal, at power plant/BR U”. Arrangement for the electricity production mix for 2005 and 2015 was based on data from the Brazilian Energy Balance corresponding to those years (EPE, 2005, 2015).

\subsubsection{Life Cycle Impact Assessment (LCIA)}

The LCIA was performed in two levels. In the first, the impacts related to the resource consumption were calculated by the method Cumulative Energy Demand (CED) v. 1.09 (Frischknecht et al. 2007). This approach allows estimations of Primary Energy Demand (PED) for different non-renewable (fossil: NRF; nuclear: NRN; and biomass: NRB) and renewable (biomass: RB; wind: RWD; and water: RWA) sources. In the second level the environmental effects of emissions that occur along the production chain has been determined. The method ReCiPe - Midpoint (H) v. 1.12 (Goedkoop et al., 2013) was applied in order to establish an impact profile that considers the impact categories of: Climate Change (CC), Terrestrial Acidification (TA), Particulate Matter Formation (PMF), Ionizing Radiation (IRad), Terrestrial Ecotoxicity (TEC), Human Toxicity (HT), and Water Depletion (WD).

\section{Results and Discussion}

Table 3 presents the 2030 Brazilian Electricity Matrix resulting from the optimization process. Results show that electricity generation from renewable sources represents $88 \%$ of total national production in 2030. Hydropower generation exceeds that of 2005 and 2015 with 272 and 281 TWh respectively; generation from wind systems is the second highest in the 2030 mix with an expansion of 183 TWh compared to the performance of 2005 and 163 TWh in relation to 2015. Still within renewable sources, the participation of biomass in the projected scenario decreases 4.3 TWh in contrast to 2015 .

Table 3. Brazilian Electricity Matrix - 2030

\begin{tabular}{lcc}
\hline Source & TWh/year & $\%$ \\
\hline Hydropower & 675 & 65.5 \\
Biomass & 46.5 & 4.51 \\
Wind & 184 & 17.9 \\
Natural Gas & 75.0 & 7.28 \\
Oil derivatives & 0.00 & 0.00 \\
Nuclear & 49.4 & 4.80 \\
Solar & 0.00 & 0.00 \\
Coal and coal products & $1.12 \mathrm{E}-01$ & 0.01 \\
Total & 1,030 & 100 \\
\hline
\end{tabular}

Note. Biomass refers only to sugarcane bagasse.

In terms of fossil sources, the expected participation is of $7.3 \%$ in the $2030 \mathrm{mix}$, with a generation $166 \%$ higher than in 2005, mainly due to the augmentation of natural gas use, and 45\% lower than in 2015 due to less coal and oil consumption. Natural gas systems expand 61 TWh in relation to 2005 while regarding 2015 this contribution decreased in 4.5 TWh. Other findings shown that nuclear sources increase $40 \mathrm{TWh}$ in relation to 2005 and $35 \mathrm{TWh}$ compared to 2015 .

Considering the $\left(C_{i}\right)$ parameters indicates in Table 2 , in terms of costs the minimum value for the electricity matrix in 2030 is USD 84.5 billion/yr, 47\% higher than in 2015 and 169\% higher than in 2005 assuming the same unit costs per source of electricity supply in all cases. As renewable sources such as wind, are more expensive than the conventional non-renewable coal and natural gas, have the largest participation in reducing GHG emissions at the same time it ensures the electricity supply. In relative terms, this trend reverses since the amount of electricity produced increases in the period 2005-2030; in that case, the respective costs of the electric arrays for the years 2005, 2015, and 2030 are: 113 USD / MWh, 93 USD / MWh, and 82 USD / MWh.

The environmental performances of the Brazilian electricity matrix associated to the generation of $1.0 \mathrm{MWh}$ of electricity in 2005, 2015, and 2030 are presented in Table 4. Regarding the Primary Energy Demand, results are mainly influenced by the water required for hydropower systems and the depletion of fossil resources, generating an increase of $7.6 \%$ in PED results from 2005 to 2030 , whereas a reduction of $18 \%$ has been observed in relation to 2015. 
Table 4. Environmental Performance of the Brazilian Electricity Supply for the production of 1.0 MWh of electricity

\begin{tabular}{ccccc}
\hline Impact Category & Units & 2005 & 2015 & 2030 \\
\hline PED & GJ & 4.59 & 6.04 & 4.94 \\
CC & $\mathrm{kg} \mathrm{CO}_{2}$ eq & 204 & 326 & 180 \\
TA & $\mathrm{kg} \mathrm{SO}_{2}$ eq & $2.40 \mathrm{E}-01$ & $9.00 \mathrm{E}-01$ & $4.40 \mathrm{E}-01$ \\
HT & $\mathrm{kg} \mathrm{1.4-DB} \mathrm{eq}$ & 8.23 & 28.9 & 14.6 \\
PMF & $\mathrm{kg} \mathrm{PM}_{10}$ eq & $6.89 \mathrm{E}-02$ & $2.17 \mathrm{E}-01$ & $1.11 \mathrm{E}-01$ \\
TEC & $\mathrm{kg} \mathrm{1.4-DB} \mathrm{eq}$ & $4.78 \mathrm{E}-03$ & $3.84 \mathrm{E}-01$ & $2.13 \mathrm{E}-01$ \\
IRad & $\mathrm{kBq} \mathrm{U235} \mathrm{eq}$ & 25.4 & 28.7 & 52.9 \\
WD & $\mathrm{m}^{3}$ & 2.79 & 7.30 & $7.8 \mathrm{E}-01$ \\
\hline
\end{tabular}

Water for hydroelectricity generation represents the highest quotas of the total PED in 2005 , of about $75 \%$, and 2030 , of $50 \%$. In 2015, this percentage achieved $40 \%$, the second most important contribution, only surpassed by depletion of fossil resources, $(46 \%)$. The nuclear resource demand has a higher influence on the total PED result in 2030 than in the other years, due to its prominent participation in the national electricity matrix to compensate for the significant reduction of fossil fuel consumption, as part of the strategy to reduce GHG emissions. The analysis showed that by 2030 , the impact in terms of CC would be reduced by $12 \%$ from the baseline scenario for 2005 , and by $45 \%$ compared to 2015 . In all cases, the main contributions to $\mathrm{CC}$ are due to atmospheric losses of $\mathrm{CO}_{2}$ from land transformation $\left(\mathrm{CO}_{2, \mathrm{LT}}\right), \mathrm{CO}_{2}$ of fossil origin $\left(\mathrm{CO}_{2, \mathrm{f}}\right)$ and biogenic methane $\left(\mathrm{CH}_{4, \mathrm{~b}}\right)$. The $\mathrm{CO}_{2, \mathrm{LT}}$ represents emissions of $\mathrm{CO}_{2}$ provided by clear cutting and land transformation due to the conversion of primary forest to agriculture and pastureland (Schmidinger and Stehfest 2012; Beck 2013). In relation to the Brazilian Electricity Matrix emissions of $\mathrm{CO}_{2, \text { LT }}$ are prevailing in hydroelectric plants due to biomass that were covered by water during the formation of the dams. Between 2005 and 2030 these losses are reduced by $28 \%$.

$\mathrm{CH}_{4, \mathrm{~b}}$ arises from methanogenesis, a biological process widely found in nature in which bacteria generate $\mathrm{CH}_{4}$ by several pathways, including $\mathrm{CO}_{2}$ reduction (Beecy et al. 2001). The flooding of forest areas for dam constructions has also been an important driver of methanogenesis when the main Brazilian hydroelectric plants were installed. However, this effect does tend to be dampened from 2005 to 2030, projecting a 27\% reduction in emissions of this $\mathrm{CC}$ precursor. Also along the same period, it was noticed a reduction of $9.0 \%$ in emissions of $\mathrm{CO}_{2, \mathrm{f}}$, stemming from burning of fossil fuels, because the decrease of coal and oil products for electricity generation.

Despite these results, all the other impact categories analyzed in the study, except for WD, show worse results in 2030 in comparison with 2005. A different behavior is seen when such results are compared with those of 2015; in this case, an impact reduction for all the analyzed categories, except IRad, is achieved between that moments.

For TA and PMF, gaseous emissions of sulfur dioxide $\left(\mathrm{SO}_{2}\right)$, occurred during the natural gas processing, and nitrogen oxides $\left(\mathrm{NO}_{\mathrm{x}}\right)$, resulting from the burning of fossil fuels, account for the largest contributions. In terms of $\mathrm{TA}$, losses of $\mathrm{SO}_{2}$ increased $187 \mathrm{~g} / \mathrm{MWh}$, while releases of $\mathrm{NO}_{\mathrm{x}}$ rose $900 \mathrm{mg} / \mathrm{MWh}$ in relation to 2005 . In both cases, the increments are due to a larger participation of natural gas in the electricity matrix for 2030. Between 2015 and 2030 these emissions are likely to be reduced $383 \mathrm{~g} / \mathrm{MWh}$ and $132 \mathrm{~g} / \mathrm{MWh}$ respectively, generating a total impact reduction of $51 \%$ during that period. For PMF, losses of $\mathrm{SO}_{2}$ increase $186 \mathrm{~g} / \mathrm{MWh}$ respecting 2005 , while air emissions of $\mathrm{NO}_{\mathrm{x}}$ get higher in $1.40 \mathrm{~g} / \mathrm{MWh}$ resulting in a total impact increment of $62 \%$. Conversely, abatements of $386 \mathrm{~g} \mathrm{SO}_{2} / \mathrm{MWh}$ and $129 \mathrm{~g} \mathrm{NO}_{\mathrm{x}} / \mathrm{MWh}$ are achieved, generating a total impact reduction for PMF of $50 \%$ in relation to 2015 .

Results for HT are influenced by the emissions of barium (Ba), manganese $(\mathrm{Mg})$ and arsenic (As) to water, arising from the extraction of natural gas, the disposal of spoil from coal mining, and disposal of uranium tailings. For the projected 2030 scenario, losses of $\mathrm{Ba}$ and As increase $10 \mathrm{~g} / \mathrm{MWh}$ and $32 \mathrm{mg} / \mathrm{MWh}$ respectively, as natural gas and uranium consumption increase in relation to 2005. Manganese emissions are $343 \mathrm{mg} / \mathrm{MWh}$ lower since coal participation is reduced in the hypothetical future matrix. In this case, a total impact increase of $79 \%$ is obtained. Between 2015 and 2030, there is a reduction of 49\%, as Ba and Mn emissions undergo respective depletions of 16 $\mathrm{g} / \mathrm{MWh}$ and $8.0 \mathrm{~g} / \mathrm{MWh}$.

Losses of bromine $(\mathrm{Br})$ for water, resulting mainly from natural gas extraction, are responsible for $81 \%$ of the total impact for TEC in 2005, while in 2015 and 2030 that contribution is $4.0 \%$. That emissions derive from the sugarcane cultivation, basically from the use of herbicides, and have the largest contributions for the total impact, contrary to the 2005 scenario, in which sugarcane biomass is not used as a source for electricity generation. 
Between 2005 and 2030 the total impact for this category increases $206 \mathrm{~g} 1.4 \mathrm{DB}_{\mathrm{eq}} / \mathrm{MWh}$, whereas from 2015 to 2030 the effect is $165 \mathrm{~g} 1.4 \mathrm{DB}$ eq $/ \mathrm{MWh}$ smaller.

Regarding IRad, losses of Radon-222 and Carbon-14, derived from nuclear power plants, account for almost $90 \%$ of the total impact for the category. In the optimized scenario, the same emissions increase of $18 \mathrm{MBq} / \mathrm{MWh}$ and, about, $600 \mathrm{~Bq} / \mathrm{MWh}$ respectively in relation to 2005 , due to the larger participation of the nuclear source in the electricity matrix. A total impact increase of $108 \%$ is generated for this category. Similar results were obtained for the period between 2015 and 2030, in which the accumulated impact increase of $84 \%$ is expected. Finally, in terms of WD, a reduction of $72 \%$ occurs in the projected scenario for 2030 compared with 2005 , as a result of the non-participation of thermoelectric oil plants in the electricity offer. Regarding 2015 this decrease achieved $89 \%$. In the baseline scenario the energy systems supported by oil products presented a contribution of $80 \%$ for the total impact in the category. It is worth highlighting that nuclear power generation, which have an important participation in the 2030 matrix, inhibit other possible gains for WD because of water consumption in cooling towers.

Even though the participation of wind power generation is significantly increased in the Brazilian Electricity mix for 2030, the share of an important renewable source, as biomass, is reduced in relation to 2015, mainly due to economic factors, which in turn favor nuclear generation, a non-renewable source. The performance shown by nuclear power endorse the conclusion of Beak (2016) and Gralla et al. (2017) that this source seems to be a potential alternative in the search for mitigating impacts caused be $\mathrm{CO}_{2}$ emissions. This is because during its entire life cycle, these emissions result to be lower than for other sources. From an economic perspective, nuclear systems, together with hydroelectric power plants, prove to be advantageous as well. However, the atomic power is still a controversial issue because of the diverse processes involved in its supply chain, ranging from uranium extraction to radioactive waste disposal and operational safety.

The nuclear participation in the Brazilian Electricity mix for 2030 is significant, so are its adverse effects in terms of IRad and HT. Therefore, a rearrangement of that hypothetical matrix has been proposed with the aim of reducing such impacts. For this reason, a new optimization has been carried out reducing the maximum capacity for nuclear power generation, and maintaining the limits established in the previous analysis for the other sources. The new restriction for nuclear energy was obtained through an iterative process, exercised until it was reached the maximum possible reduction for that source, which would still meet the impact and demand requirements established in section 2. Taking into account those restrictions a participation of $34 \mathrm{TWh}$ has been reached as the upper limit for nuclear source. Table 5 describes the composition of the alternative matrix, defined as 2030'.

Table 5. Brazilian Electricity Matrix - 2030’ with restriction of nuclear power production

\begin{tabular}{lcc}
\hline Source & TWh/year & $\%$ \\
\hline Hydropower & 675 & 65.5 \\
Biomass & 51.2 & 4.97 \\
Wind & 195 & 18.9 \\
Natural Gas & 75.0 & 7.28 \\
Oil derivatives & 0.00 & 0.00 \\
Nuclear & 33.9 & 3.29 \\
Solar & 0.00 & 0.00 \\
Coal and coal products & $1.24 \mathrm{E}-03$ & $1.20 \mathrm{E}-04$ \\
Total & 1,030 & 100 \\
\hline
\end{tabular}

Note. Biomass refers only to sugarcane bagasse.

The reduction in the nuclear contribution $(4.8 \% \rightarrow 3.3 \%)$ generates an increase in the share of the wind source, which reached its established upper limit (Table 2). Thus, the biomass completes the array until the demand is met. Results for the environmental performance of both mixes (2030 and 2030') are presented in Table 6.

Regarding PED, we noted a reduction of $2.4 \%$ from 2030 to $2030^{\prime}$ as consumption of nuclear resources diminished in $31 \%$. For HT, an impact reduction of $2.0 \%$ is achieved in the $2030^{\prime}$ mix, due to the decrease, in $16 \%$, in the emissions to water of As, caused by disposal of uranium tailings. For IRad, the impact abatement was still more significant (31\%), once again due to the drop in the share of atomic energy. Finally, still as a side effect of that action WD results $16 \%$ lower than that calculated for 2030. Conversely, the changes of the 2030 mix generated an impact increment of $9.5 \%$ for TEC, due to the increased participation of biomass in the new mix done in order to compensate for the reduction in consumption of nuclear sources. 
Table 6. Environmental Performance of the Brazilian Electricity Supply for the production of 1.0 MWh of electricity for the 2030 and 2030 ' scenarios

\begin{tabular}{cccc}
\hline Impact Category & Units & 2030 & 2030 \\
\hline PED & $\mathrm{GJ}$ & 4.94 & 4.82 \\
$\mathrm{CC}$ & $\mathrm{kg} \mathrm{CO}_{2}$ eq & 180 & 180 \\
$\mathrm{TA}$ & $\mathrm{kg} \mathrm{SO}_{2}$ eq & $4.4 \mathrm{E}-01$ & $4.4 \mathrm{E}-01$ \\
$\mathrm{HT}$ & $\mathrm{kg} \mathrm{1.4-DB} \mathrm{eq}$ & 14.6 & 14.3 \\
PMF & $\mathrm{kg} \mathrm{PM}_{10}$ eq & $1.1 \mathrm{E}-01$ & $1.1 \mathrm{E}-01$ \\
TEC & $\mathrm{kg} \mathrm{1.4-DB} \mathrm{eq}$ & $2.1 \mathrm{E}-01$ & $2.3 \mathrm{E}-01$ \\
IRad & $\mathrm{kBq} \mathrm{U} 235$ eq & 52.9 & 36.6 \\
WD & $\mathrm{m}^{3}$ & $7.8 \mathrm{E}-01$ & $6.53 \mathrm{E}-01$ \\
\hline
\end{tabular}

From the presented results, we point out that not all systems for electric generation can satisfactorily meet every economic, environmental and social criteria. For instance, reductions in CC are achieved as planned between 2005 and 2030. Nevertheless, impacts for other categories show significant increases: for the alternative 2030' array, there are impact decreases for IRad and HT as expected; however, results for TEC are worse. In this context, economic, environmental, and social criteria must be prioritized and the consequences and impacts derived from the decision-making process for the defining the electricity matrix must be evaluated as well.

\section{Conclusions}

The present study projected a Brazilian electrical matrix for 2030, in which three main objectives should be achieved: (i) electricity matrix with minimum generation cost; (ii) reduction of impact in terms of GHG, respecting 2005; and (iii) supply of the projected electricity demand for 2030. Results showed that electricity generation from renewable sources represent $88 \%$ of the national production in 2030, with hydropower responsible for most of this generation. Electricity from wind sources has the second largest participation in the national supply (18\%), followed by natural gas, with a contribution of $7.3 \%$. Together, the fossil sources provide $75 \mathrm{TWh}, 45 \%$ lower than in 2015; in this group, natural gas responds for most of this production, while coal and its products have a modest participation. The oil sources leave the electricity supply in 2030. In terms of costs, the minimum value for the 2030 electricity matrix is USD 84.5 billion, as renewable sources such as wind, generally more expensive than conventional non-renewable sources (coal and natural gas) have a larger participation. In relative terms, this cost reaches USD 82/MWh.

The environmental performance shows that, as expected, the impact in terms of Climate Change (CC) is reduced $12 \%$ respecting 2005 , and $45 \%$ respecting 2015 . Other category that results in an important impact reduction is Water Depletion (WD); 72\% and 89\% reductions are achieved between 2005-2030 and 2015-2030, respectively.

Despite these favorable results, the national 2030 matrix has a worse performance for the rest of the analyzed categories compared to the 2005 scenario, highlighting Terrestrial Ecotoxicity (TEC), which the performance is more than forty times higher than the baseline scenario, and Ionizing Radiation (IRad), in which the increment was $108 \%$. TEC impacts are due to the use of pesticides in the sugarcane cultivation, whereas the disposal of tailings from uranium milling account for most of the impact in terms of IRad. Regarding 2015, results show a better performance for all the studied categories, with reductions above $45 \%$, except IRad, which increases $84 \%$.

Finally, in terms of Primary Energy Demand (PED), an increase of 7.6\% is expected between 2005 and 2030 but a total PED reduction of $18 \%$ is achieved between 2015 and 2030. Water for hydroelectricity generation demands $50 \%$ of the total PED in 2030, followed by fossil generation which contribute 19\%. For the proposed 2030' array, respective reductions of $2.0 \%$ and $31 \%$ for $\mathrm{HT}$ and IRad are obtained respecting the 2030 mix, but with negative results for TEC, whose impact was increased $9.5 \%$ respecting the 2030 result.

In conclusion, the findings of this study suggest that the process of achieving a reduction in GHG emissions of 12\% in comparison with 2005, incurs negative outcomes in other impact categories. This reinforces the importance of conducting analyses such as those provided by the Life Cycle Assessment approach, and include these results in the planning and decision-making processes of the energy sector. In addition to this, environmental management should not be limited to GHG analysis, and indeed must encompass other equally important impacts when it comes to environmental preservation and sustainable development.

\section{Acknowledgements}

Claudia C. S. Moore acknowledge the financial support from Coordination for the Improvement of Higher Education Personnel (CAPES) through a doctoral scholarship (PROEX/0487 - Process: 1658812). 


\section{References}

Abbaspour, M., Monavari, M., Karbassi R., \& Kargari, N. (2011). Nuclear power and its role in $\mathrm{CO}_{2}$ emissions from the electricity generation in Iran. Energy Sources Part A, 34, 43-52. https://doi.org/10.1080/15567036. 2010.483532

Agarski, B., Budak, I., Vukelic, D., \& Hodolic, J. (2016). Fuzzy multi-criteria-based impact category weighting in life cycle assessment. Journal of Cleaner Production, 112, 3256-3266. https://doi.org/10.1016/j.jclepro.2015. 09.077

Alam, M. M., Murad, M. W., Norman, A. H. M., \& Ozturk, I. (2016). Relationships among carbon emissions, economic growth, energy consumption and population growth: testing environmental Kuznets Curve hypothesis for Brazil, China, India and Indonesia. Ecological Indicators, 70, 466-479. https://doi.org/10. 1016/j.ecolind.2016.06.043

Almer, C. \& Winkler, R. (2017). Analyzing the effectiveness of international environmental policies: The case of the Kyoto Protocol. Journal of Environmental Economics and Management, 82, 125-151. https://doi.org/10. 1016/j.jeem.2016.11.003

Baek, J, (2016). Do nuclear and renewable energy improve the environment? Empirical evidence from the United States. Ecological Indicators, 66, 352-356. https://doi.org/10.1016/j.ecolind.2016.01.059

Beck, T. (2013). Principles of Ecological Landscape Design (pp. 245-249). Island Press. Washington DC. US.

Beecy, D. J., Ferrell, F. M., \& Carey, J. K. (2001). Biogenic Methane: A Long-Term $\mathrm{CO}_{2}$ Recycle Concept. The US Department of Energy Carbon Sequestration Research Program. Retrieved from https:/www.netl. doe.gov/publications/proceedings/01/carbon_seq/5a1.pdf

Blok, V., Long, T. B, Gaziulusoy, A. I, Ciliz, N., Lozano, R., Huisingh, D., Csutora, M., Boks. C. (2015). From best practices to bridges for a more sustainable future: advances and challenges in the transition to global sustainable production and consumption. Journal of Cleaner Production, 108, 19-30. https://doi.org/10.1016/ j.jclepro.2015.04.119

Burger, B., \& Bauer, C. (2007). Windkraft. In: Sachbilanzen von Energiesystemen: Grundlagen für den ökologischen Vergleich von Energiesystemen und den Einbezug von Energiesystemen in Ökobilanzen für die Schweiz, ecoinvent report No. 6-XIII, v2.0 (ed. Dones R.). Paul Scherrer Institut Villigen, Swiss Centre for Life Cycle Inventories, Dübendorf, Switzerland. 2007.

Chen, C., Long, H., \& Zeng, X. (2017). Planning a sustainable urban electric power system with considering effects of new energy resources and clean production levels under uncertainty: A case study of Tianjin, China. Journal of Cleaner Production (in press). https://doi.org/10.1016/j.jclepro.2017.01.098

Costa, O. L. V., Ribeiro, C. O., Rego, E. E., Stern, J. M, Parente, V., \& Kileber, S. (2017) Robust portfolio optimization for electricity planning: An application based on the Brazilian electricity mix. Energy Economics, 64, 158-169. https://doi.org/10.1016/j.eneco.2017.03.021

Dantas, G. A., Castro, N. J., Brandão, R., Rosental, R., \& Lafranque, A. (2017). Prospects for the Brazilian electricity sector in the 2030s: Scenarios and guidelines for its transformation. Renewable and Sustainable Energy Reviews, 68, 997-1007. https://doi.org/10.1016/j.rser.2016.08.003

Dinato, R., \& Kulay, L. (2015). The fossilization of the Brazilian electric matrix under the Life Cycle Assessment perspective. Paper presented at the 2nd Discussion Forum on Industrial Ecology and Life-Cycle Management, Coimbra. Retrieved from http://bibliotecadigital.fgv.br/dspace/handle/10438/18468

Dones, R. (2007) Kernenergie. In: Sachbilanzen von Energiesystemen: Grundlagen für den ökologischen Vergleich von Energiesystemen und den Einbezug von Energiesystemen in Ökobilanzen für die Schweiz (Ed. Dones R.). Final report Ecoinvent. No. 6-VII. Paul Scherrer Institut Villigen, Swiss Centre for LCI, Dübendorf, Switzerland. 2007b.

Dones, R. (2007). Life Cycle Inventories of Energy Systems: Results for current systems in Switzerland and other UCTE countries. Ecoinvent Report N.5. Swiss Centre for LCI, Dübendorf, Switzerland, 2007a, retrieved from www.ecoinvent.org

Elum, Z. A., \& Momodu, A. S. (2017). Climate change mitigation and renewable energy for sustainable development in Nigeria: A discourse approach. Renewable and Sustainable Energy Reviews, 76, $72-80$. https://doi.org/10.1016/j.rser.2017.03.040 
EPE - Energy Research Company. National Energy Balance 2006. (Base year: 2005). Final Report. Retrieved April 2017, from http://http://www.mme.gov.br

EPE - Energy Research Company. National Energy Balance 2016. (Base year: 2015). Final Report. Retrieved April 2017, from http:// http://www.mme.gov.br

Faist Emmenegger M., Heck, T., \& Jungbluth, N. (2007). Erdgas. In: Sachbilanzen von Energiesystemen: Grundlagen für den ökologischen Vergleich von Energiesystemen und den Einbezug von Energiesystemen in Ökobilanzen für die Schweiz, ecoinvent report No. 6-V, v2.0 (ed. Dones R.). Paul Scherrer Institut Villigen, Swiss Centre for Life Cycle Inventories, Dübendorf, Switzerland. 2007.

Foley, A., Smyth, B. M., Pukšec, T., Markovska, N., \& Duić, N. (2017). A review of developments in technologies and research that have had a direct measurable impact on sustainability considering the Paris agreement on climate change. Renewable and Sustainable Energy Reviews, 68, 835-839. https://doi.org/10.1016/ j.rser.2016.11.215

Frischknecht R. (2007). Implementation of Life Cycle Impact Assessment Methods. Final report Ecoinvent v2 (pp. 31-38). Swiss Centre for LCI. Dübendorf, Switzerland.

Goedkoop, M., Heijungs, R., Huijbregts, M., De Schryver, A. \& Struijs, J. (2017). Description of the ReCiPe methodology for Life Assessment Impact Assessment. http://www.lcia-recipe.net. Retrieved may 2017

Gralla, F., Abson, D. J., Møller, A. P., Lang, D. J., \& von Wehrden, H. (2017). Energy transitions and national development indicators: A global review of nuclear energy production. Renewable and Sustainable Energy Reviews, 70, 1251-1265. https://doi.org/10.1016/j.rser.2016.12.026

Grilli, G., Balest, J., De Meo, I., Garegnani, G., \& Paletto, A. (2016). Experts' opinions on the effects of renewable energy development on ecosystem services in the Alpine region. Journal of Renewable and Sustainable Energy, 8, 1-13. https://doi.org/10.1063/1.4943010

Grilli, G., De Meo, I., Garegnani, G., \& Paletto, A. (2017). A multi-criteria framework to assess the sustainability of renewable energy development in the Alps. Journal of Environmental Planning and Management, 60, 1-20. https://doi.org/10.1080/09640568.2016.1216398

Gueller, M. T. B., \& Meneses, A. A. M. (2016). Life Cycle Assessment of a small hydropower plant in the Brazilian amazon". Journal of Sustainable Development of Energy, Water and Environmental Systems, 4, 379-391. https://doi.org/10.13044/j.sdewes.2016.04.0029

Guerra, J. B. S. O. A, Dutra, L., Schwinden, N. B. C., \& Andrade, S. F (2015). Future scenarios and trends in energy generation in Brazil: supply and demand and mitigation forecasts. Journal of Cleaner Production, 103, 197-210. https://doi.org/10.1016/j.jclepro.2014.09.082

Hacatoglu, K., Dincer, I., \& Rosen, M. A. (2015). A new model to assess the environmental impact and sustainability of energy systems. Journal of Cleaner Production, 103, 211-218. https://doi.org/10.1016/ j.jclepro.2014.06.050

Hardisty, P. E., Clark, T. S., \& Hynes, R. G. (2012). Life Cycle Green House Gas emissions from electricity generation: a comparative analysis of Australian energy sources. Energies, 5, 872-897. https://doi.org/10. $3390 /$ en5040872

IEA - International Energy Agency. (2015). Projected Costs of Generating Electricity OECD Publishing, Paris. 2015. Retrieved April, 2017 from https://www.oecd-nea.org/ndd/pubs/2015/7057-proj-costs-electricity -2015.pdf

ISO - International Organization for Standardization. (2006). ISO 14044, Environmental management - Life cycle assessment - Requirements and guidelines. Genève. 46p.

Jacobi, P. R., Cibim, J., \& Leão, R. S. (2015). Crise hídrica na Macrometrópole Paulista e respostas da sociedade civil. Estudos Avançados, 29, 27-42. https://doi.org/10.1590/S0103-40142015000200003

Jungbluth, N., \& Erdöl. (2007). In R. Dones (ed.), Sachbilanzen von Energiesystemen: Grundlagen für den ökologischen Vergleich von Energiesystemen und den Einbezug von Energiesystemen in Ökobilanzen für die Schweiz. Ecoinvent report No. 6-IV. Dübendorf: Swiss Centre for LCI, 2007.

Jungbluth, N., \& Tuchschmid, M. (2007). Photovoltaics. In: Sachbilanzen von Energiesystemen: Grundlagen für den ökologischen Vergleich von Energiesystemen und den Einbezug von Energiesystemen in Ökobilanzen für die Schweiz, ecoinvent report No. 6-XII, v2.0 (ed. Dones R.). pp. 180. Paul Scherrer Institut Villigen, Swiss Centre for LCI, Dübendorf, Switzerland. 2007. 
Jungbluth, N., Chudacoff, M., Dauriat, A., Dinkel, F., Doka, G., Faist Emmenegger, M., ... Sutter, J. (2007). Life Cycle Inventories of Bioenergy. Ecoinvent report N. 17. Swiss Centre for LCI. Dübendorf, Switzerland. 2007.

Kileber, S., \& Parente, V. (2015), Diversifying the Brazilian electricity mix: Income level, the endowment effect, and governance capacity. Renewable and Sustainable Energy Reviews, 49, 1180-1189. https://doi.org/10. 1016/j.rser.2015.04.109

Lau, L. C., Lee, K. T., \& Mohamed, A. R. (2012). Global warming mitigation and renewable energy policy development from the Kyoto Protocol to the Copenhagen Accord - A comment. Renewable and Sustainable Energy Reviews, 16, 5280-5284. https://doi: doi.org/10.1016/j.rser.2012.04.006

Lima, C. C., \& Carvalho, L. M. O. (2016). A produção de Energia Elétrica, a exaustão ambiental da fonte hídrica e a opção proveniente da base eólica renovável. Revista Brasileira de Energias Renováveis, 5, 65-90. https://doi.org/10.5380/rber.v5i1.43558

LINGO - Optimization Modeling Software for Linear, Nonlinear, and Integer Programming v. 17.0.0.52. 2017, computer program, LINDO Systems Inc. Chicago. US. Retrieved April 2017, from http://www.lindo.com

Maxim, A. (2014). Sustainability assessment of electricity generation technologies using weighted multi-criteria decision analysis. Energy Policy, 65, 284-297. https://doi.org/10.1016/j.enpol.2013.09.059

MME - Ministry of Mines and Energy. (2007). National Energy Grid 2030. Brasília, 2007, 254 p. Retrieved March, 2017, from http://www.mme.gov.br

Moreira, J. M. L., Cesaretti, M. A., Carajilescov, P., \& Maiorino, J. R. (2015). Sustainability deterioration of electricity generation in Brazil. Energy Policy, 87, 334-346. https://doi.org/10.1016/j.enpol.2015.09.021

Mossalanejad, A. (2012). Evaluating the developed countries policy making toward environmental cases. International Journal of Environmental Research, 6, 71-80. https://doi.org/10.22059/IJER.2011.473

MRE - Ministry of Foreign Affairs. (2017). Pretendida Contribuição Nacionalmente Determinada para consecução do objetivo da Convenção-Quadro das Nações Unidas sobre Mudança do Clima. 10 p. Brasília, 2015. Retrieved March 2017, from http://www.itamaraty.gov.br/images/ed_desenvsust/BRASIL -iNDC-portugues.pdf

Pao, H. T., \& Fu, H. C. (2013). Renewable energy, non-renewable energy and economic growth in Brazil. Renewable and Sustainable Energy Review, 25, 381-392. https://doi.org/10.1016/j.rser.2013.05.004

Patel, M., Zhang, X., \& Kumar, A. (2016). Techno-economic and life cycle assessment on lignocellulosic biomass thermochemical conversion technologies: A review. Renewable and Sustainable Energy Review, 53, 1486-1499. https://doi.org/10.1016/j.rser.2015.09.070

Pereira, M. G., Camacho, C. F., Freitas, M. A. V., \& Silva, N.F. (2012). The renewable energy market in Brazil: Current status and potential. Renewable and Sustainable Energy Review, 16, 3786-3802. https://doi.org/0. 1016/j.rser.2012.03.024

Portugal-Pereira, J., Köberle, A. C., Soria, R., Lucena, A. F. P., Szklo, A., \& Schaeffer, R. (2016). Overlooked impacts of electricity expansion optimisation modelling: The life cycle side of the story. Energy, 115, 1424-1435. https://doi.org/10.1016/j.energy.2016.03.062

Rocha, G. O., Dos Anjos, J. P., \& Andrade, J. B. (2015). Energy trends and the water-energy binomium for Brazil. Annals of the Brazilian Academy of Sciences, 87, 569-594. https://doi.org/10.1590/0001-3765201520140560

Röder, A., Bauer, C., \& Dones, R. (2004). In: Sachbilanzen von Energiesystemen: Grundlagen für den ökologischen Vergleich von Energiesystemen und den Einbezug von Energiesystemen in Ökobilanzen für die Schweiz (Ed. Dones R.). Final report Ecoinvent. No. 6-VI. Paul Scherrer Institut Villigen, Swiss Centre for LCI, Dübendorf, Switzerland, 2007.

Sáez-Martínez, F. J., Lefebvre, G., Hernández, J. J., \& Clark, J. H. (2016). Drivers of sustainable cleaner production and sustainable energy options. Journal of Cleaner Production, 138, 1-7. https://doi.org/10.1016/ j.jclepro.2016.08.094

Santos, M. J., Ferreira, P., Araújo, M., Portugal-Pereira, J., Lucena, A. F. P., \& Schaeffer, R. (2017). Scenarios for the future Brazilian power sector based on a multi-criteria assessment. Journal of Cleaner Production (in press). https://doi.org/10.1016/j.jclepro.2017.03.145 
Santoyo-Castelazo, E., \& Azapagic, A. (2014). Sustainability assessment of energy systems: integrating environmental, economic and social aspects. Journal of Cleaner Production, 80, 119-138. https://doi.org/10. 1016/j.jclepro.2014.05.061

Schmidinger, K., \& Stehfest, E. (2012). Including $\mathrm{CO}_{2}$ implications of land occupation in LCAs - method and example for livestock products. International Journal of Life Cycle Assessment, 17, 962-972. https://doi.org/10.1007/s1 1367-012-0434-7

ShafiepourMotlagh, M., Ashrafi, Kh., \& Dalir, F. (2016). LCA frameworks integration in Carbon Footprint modelling of simple cycle and combined cycle power plant for sustainable planning in Iran. International Journal of Environmental Research, 10, 645-654. https://doi.org/10.22059/IJER.2016.59969

Sims, R. E. H. (2007). Energy supply. In Climate Change 2007: Mitigation. Contribution of Working Group III to the $4^{\text {th }}$ Assessment Report of the Intergovernmental Panel on Climate Change. Cambridge University Press, Cambridge, United Kingdom and New York, NY, USA. 2007. 72 p. Retrieved May 2017, from https://www.ipcc.ch/pdf/assessment-report/ar4/wg3/ar4-wg3-chapter4.pdf

Stamford, L., \& Azapagic, A. (2014). Life cycle sustainability assessment of UK electricity scenarios to 2070. Energy for sustainable Development, 23, 194-211. https://doi.org/10.1016/j.esd.2014.09.008

Turconi, R., Boldrin, A., \& Astrup, T. (2013). Life Cycle Assessment (LCA) of electricity generation technologies: overview, comparability and limitations. Renewable and Sustainable Energy Reviews, 28, 555-565. https://doi.org/10.1016/j.rser.2013.08.013

Vahl, F. P., \& Casarotto Filho, N. (2015). Energy transition and path creation for natural gas in the Brazilian electricity mix. Journal of Cleaner Production, 86, 221-229. https://doi.org/10.1016/j.jclepro.2014.08.033

Vidal-Amaro, J. J., Østergaard, P. A., \& Sheinbaum-Pardo, C. (2015). Optimal energy mix for transitioning from fossil fuels to renewable energy sources - The case of the Mexican electricity system. Applied Energy, 150, 80-96. https://doi.org/10.1016/j.apenergy.2015.03.133

Von Sperling, E. (2012) Hydropower in Brazil: overview of positive and negative environmental aspects. Energy Procedia, 18, 110-118. https://doi.org/10.1016/j.egypro.2012.05.023

Zbicinski, I., Stavenuiter, J., Kozlowska, B., \& van de Coevering, H. (2006). Product Design and Life Cycle Assessment (pp. 88-89). The Baltic University Press, Usppsala. Sweden. 2006.

\section{Copyrights}

Copyright for this article is retained by the author(s), with first publication rights granted to the journal.

This is an open-access article distributed under the terms and conditions of the Creative Commons Attribution license (http://creativecommons.org/licenses/by/4.0/). 